\title{
Human-crocodile conflict in the Indian Sundarban: an analysis of spatio-temporal incidences in relation to people's livelihood
}

\author{
Chandan Surabhi Das and Rabindranath Jana
}

\begin{abstract}
The incidence of human-crocodile conflict is increasing, and fear of injury and loss of life is affecting public and political support for crocodile conservation. We studied conflicts between people and estuarine crocodiles Crocodylus porosus across socio-economic dimensions, using a spatio-temporal database. We collected data on 127 crocodile attacks that occurred during 2000-2013, through questionnaires including open- and close-ended questions, administered in 30 villages of five blocks of the Indian Sundarban. Most of the attacks (42\%) occurred during winter (December-February), followed by the early monsoon (May-July; 27\%). Almost $80 \%$ of victims were prawn seed collectors and were $11-50$ years old, and $61.16 \%$ of victims died as a result of the attacks. Female victims accounted for a higher percentage of deaths $(55.12 \%)$ than male victims $(44.88 \%)$. Crocodile attacks were more common in the daytime than at night, with $76.35 \%$ of the killings occurring during $08.00-17.00$. Most of the cases were recorded from Gosaba (34\%), followed by Patharpratima (25.24\%) and Namkhana (18.45\%) blocks. The mean number of incidents per year was 9.07, with vulnerability and mortality rates of 0.07 and 0.04 , respectively, per 10,000 persons. Existing management practices are insufficient to eliminate the risk of crocodile attacks and ensure the conservation of the Sundarban ecosystem. A comprehensive management plan for reducing dependency on forest resources is needed to minimize human-crocodile conflict.
\end{abstract}

Keywords Crocodylus porosus, estuarine crocodile, fisher, human-crocodile conflict, India, prawn seed collector, Sundarban

\section{Introduction}

A s human populations continue to increase, people are A increasingly encroaching on natural areas. As a result, the relationship between people and wildlife is often

Chandan Surabhi Das (Corresponding author) Department of Geography, Barasat Government College, Barasat, West Bengal, India

E-mail yenisi2002@gmail.com

RABINDRANATH JANA Sociological Research Unit, Indian Statistical Institute, Kolkata, West Bengal, India

Received 13 June 2016. Revision requested 4 August 2016.

Accepted 9 November 2016. First published online 7 August 2017. antagonistic because of competition over declining resources (Weladji \& Tchamba, 2003), and thus when an increasing number of people are crowded into a limited area of land, human-wildlife conflicts are likely to increase. Such conflicts commonly arise when wildlife cause damage to crops, or kill livestock or game, and occasionally they involve attacks on people (Inskip \& Zimmermann, 2009).

Human-wildlife conflict is a growing problem worldwide (Woodroffe et al., 2005), and crocodilians are one of the major groups involved (Lamarque et al., 2009). Attacks by crocodiles and alligators are increasing in many parts of the world (Langley, 2005), including in developed nations (e.g. by saltwater crocodiles Crocodylus porosus in Australia, Caldicott et al., 2005; and by American alligators Alligator mississippiensis in the USA, Langley, 2005). Crocodiles are top predators and keystone species, and perform an important role in maintaining the biodiversity, structure and function of freshwater ecosystems (Thorbjarnarson, 1992; Ross, 1998; Leslie \& Spotila, 2001; Glen et al., 2007).

With the exception of ecotourism, interactions between people and crocodiles are rarely positive (McGregor, 2005), and developing ways to reduce conflict is essential to mitigate the loss of both human life and livestock (Fergusson, 2002). Large carnivores are often highly valued at a global scale but have a low or negative economic value at a local scale (Dickman et al., 2011). To address this, local revenue from carnivore presence should outweigh the costs of coexistence (McManus et al., 2015), such as through tourism or payments for presence. Management approaches to human-crocodile conflict include capture and relocation, and lethal control, of crocodiles. These actions need to be carefully monitored, as crocodiles are an economically important species (MacGregor, 2002).

There are three species of crocodiles in India: the estuarine or saltwater crocodile, the marsh or freshwater crocodile Crocodylus palustris and the gharial Gavialis gangeticus. All three species were formerly found in the Sundarban but the current status of freshwater crocodiles and gharials in the region in unknown (Vyas, 2012). The estuarine crocodile is the largest marine reptile in India, and its population has declined as a result of indiscriminate poaching for its valuable skin (Mandal \& Nandi, 1989), loss of habitat, and water pollution (Das \& Bandyopadhyay, 2012). There is little information available on conflict between people and estuarine crocodiles in the Sundarban but historical records reference 
its existence. During 1920-1930, when tiger Panthera tigris hunting was permitted, it was perceived that killing of people by tigers decreased and the major threat to human life was from crocodiles (Curtis, 1933; Vyas, 2012).

Estuarine crocodiles currently inhabit $2,500 \mathrm{~km}^{2}$ of the Indian Sundarban, concentrated mostly in the Saptamukhi, Thakuran, Choto Noubanki, and Mechua Khal areas (Chaudhuri, 2007). Human-crocodile conflicts have increased since 1990, mainly as a result of large-scale human encroachment into the crocodile's territories. Our objectives were to determine the nature, extent and causes of conflict between people and estuarine crocodiles in the Sundarban, using a spatio-temporal database, and to suggest appropriate management and mitigation strategies to reduce conflict.

\section{Study area}

The Sundarban is one of several areas in India prone to crocodile attacks, and was chosen as the study area because of its accessibility. The undivided Sundarban (i.e. the combined mangrove region of India and Bangladesh before 1947, comprising c. $10,000 \mathrm{~km}^{2}$ ) is the world's largest tidal mangrove forest (Chaudhuri \& Choudhury, 1994), accounting for 6\% of mangrove area globally (Khan, 2002). Reclamation of the Indian part of the Sundarban began as early as 1770 (Pargiter, 1934), and during the next 2 centuries c. $5,364 \mathrm{~km}^{2}$ of the tidal forests were converted to farmland and habitations. The study was confined to the five community development blocks (Basanti, Gosaba, Kultali, Patharpratima and Namkhana) adjacent to the forest fringe areas, with a total area of $802 \mathrm{~km}^{2}$ covering both reclaimed land and forest areas (Fig. 1). The study area supports a rapidly growing population of 4.2 million people, with a mean density of $>900$ per $\mathrm{km}^{2}$ (Census of India, 2011).

\section{Methods}

During March 2013-April 2014 we collected data using two methods. Firstly, we compiled records of crocodile attacks collected by the local government (i.e. Gram Panchayat and Block Primary Health Centres) and non-government agencies (i.e. Tagore Society for Rural Development in Gosaba, South Sundarban Janakalyan Sangha Society Information in Kakdwip, and Juktibadi Sanskritik Sanstha, Canning). Secondly, community surveys were conducted with the help of local people, using questionnaires and semistructured interviews. These surveys were conducted door-to-door in the villages of the selected blocks. Data were collected on locality (forest range, river, village and block), date, time, activity of the victim at the time of conflict, primary and secondary occupation of the victim, result of the conflict, depredation, reflexive fear, and the role of accompanying persons following attack. The questionnaire

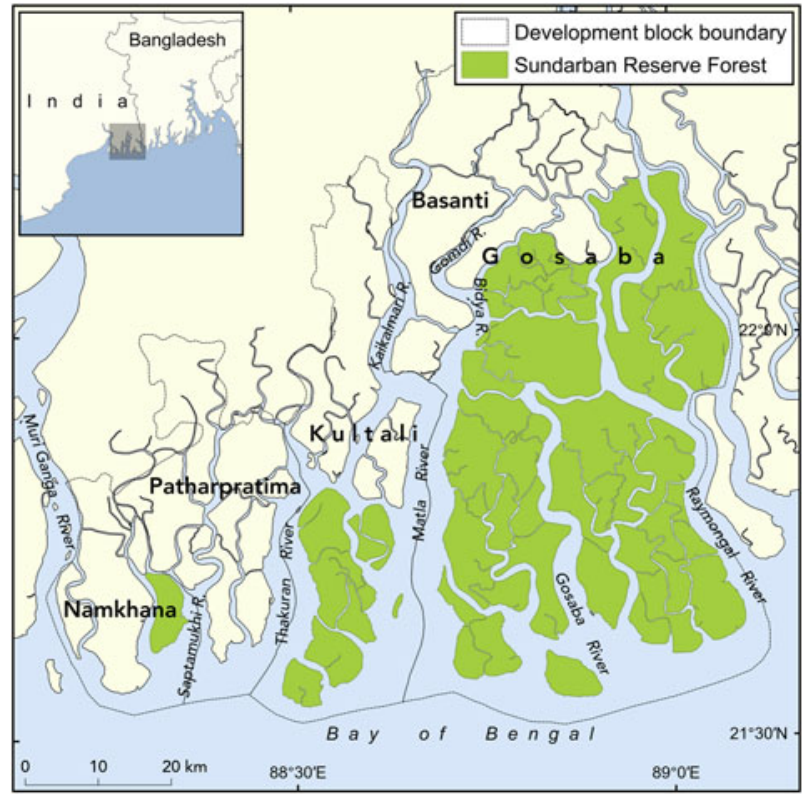

FIG. 1 Location of the five study blocks in the Indian Sundarban.

included both open-ended and fixed-response questions, and was conducted with the head of the household or his/ her representative.

Three problems were considered during the survey: (1) some non-fatal attacks are not reported to the local government, (2) incidents may be exaggerated, and (3) responses could be based on anecdotal evidence. These biases were minimized by means of a neutral introduction and nonleading question order (Milner-Gulland and Rowcliffe, 2007), and non-reported incidents were identified and recorded through the door-to-door survey.

Thirty villages were purposively selected on the basis of their location adjacent to forest or river. Thereafter, guided by the expert opinion of knowledgeable local people, we compiled a preliminary list of households in which either at least one family member was killed or injured during 2000-2013, or family members depended primarily or secondarily on aquatic resources. The list included 1,315 households. Both quantitative methods ( $\chi^{2}$ test), using SPSS 16.o (IBM, Armonk, USA), and qualitative methods (e.g. focus group discussion) were used to analyse the data.

\section{Results}

We recorded 127 incidents of human-crocodile conflict during 2000-2013, and household-level socio-economic data for each case. Most of the victims $(88.19 \%, n=112)$ were tiger prawn seed collectors (38.58\%), crab collectors $(26.77 \%)$ or fishers (22.83\%; Table 1). People whose primary occupation was prawn seed collection were the worst affected $(34.65 \%)$, followed by crab collection $(20.47 \%)$ and fishing (13.38\%). 
TABLE 1 Number of victims of crocodile Crocodylus porosus attacks in the Indian Sundarban (Fig. 1) during 2000-2013, as reported in surveys of 1,315 households, according to the victims' occupation at the time of the attack, religion and caste, and age group.

\begin{tabular}{|c|c|c|c|c|c|}
\hline \multirow[b]{2}{*}{ Socio-economic/demographic group } & \multicolumn{4}{|c|}{$\begin{array}{l}\text { Primary occupation of victim } \\
\text { (No. of deaths, no. of injuries) }\end{array}$} & \multirow[b]{2}{*}{ Total } \\
\hline & Crab collector & Fisher & Prawn seed collector & Other & \\
\hline \multicolumn{6}{|l|}{ Occupation at the time of attack } \\
\hline Crab collector & $26(20,6)$ & $2(1,1)$ & $3(3,0)$ & $2(2,0)$ & $33(26,7)$ \\
\hline Fisher & $1(1,0)$ & $17(9,8)$ & $2(2,0)$ & $4(4,0)$ & $24(16,8)$ \\
\hline Prawn seed collector & $7(4,3)$ & $10(7,3)$ & $44(34,10)$ & $9(7,2)$ & $70(52,18)$ \\
\hline Total & $34(25,9)$ & $29(17,12)$ & $49(39,10)$ & $15(13,2)$ & $127(94,33)$ \\
\hline \multicolumn{6}{|l|}{ Religion \& caste } \\
\hline Hindu (General) & $8(6,2)$ & $11(6,5)$ & $19(15,4)$ & $6(4,2)$ & $44(31,13)$ \\
\hline Hindu (Scheduled castes ${ }^{\star}$ ) & $22(16,6)$ & $11(6,5)$ & $25(19,6)$ & $7(7,0)$ & $65(48,17)$ \\
\hline Hindu (Scheduled tribes ${ }^{\star}$ ) & $4(3,1)$ & $4(4,0)$ & $3(3,0)$ & $1(1,0)$ & $12(11,1)$ \\
\hline Muslim & $0(0,0)$ & $3(1,2)$ & $2(2,0)$ & $1(1,0)$ & $6(4,2)$ \\
\hline Total & $34(25,9)$ & $29(17,12)$ & $49(39,10)$ & $15(13,2)$ & $127(94,33)$ \\
\hline \multicolumn{6}{|l|}{ Age group } \\
\hline Pre-adult $(<18$ years $)$ & $2(2,0)$ & $1(1,0)$ & $11(8,3)$ & $1(1,0)$ & $15(12,3)$ \\
\hline Junior adult (18-30 years) & $8(6,2)$ & $5(2,3)$ & $13(12,1)$ & $6(6,0)$ & $32(26,6)$ \\
\hline Middle adult ( $31-50$ years) & $20(14,6)$ & $16(10,6)$ & $21(15,6)$ & $8(6,2)$ & $65(45,20)$ \\
\hline Senior adult ( $>50$ years) & $4(3,1)$ & $7(4,3)$ & $4(4,0)$ & $0(0,0)$ & $15(11,4)$ \\
\hline Total & $34(25,9)$ & $29(17,12)$ & $49(39,10)$ & $15(13,2)$ & $127(94,33)$ \\
\hline
\end{tabular}

*Scheduled castes and scheduled tribes are official designations given to various groups of historically disadvantaged indigenous people in India. The terms are recognized in the Constitution of India. During the period of British rule in the Indian subcontinent they were known as the Depressed Classes.

All castes, as defined in the Census of India (2011), were affected by the conflict (Table 1). Scheduled castes were the worst affected $(51.18 \%)$, followed by general caste $(34.65 \%)$ and scheduled tribes (9.45\%). Among prawn seed collectors scheduled castes (47.14\%) were affected at marginally higher rates than the general caste population (38.57\%). Hindus were affected more by conflict with crocodiles (95.28\%) than Muslims (4.72\%). However, the caste and occupation of victims were not significantly associated $\left(\chi^{2}=9.115\right.$, $\mathrm{df}=9, \mathrm{P}>0.05)$.

We grouped victims into four age categories: pre-adult, $<18$ years; junior adult, $18-30$ years; middle adult, $31-50$ years; senior adult, $>50$ years (Table 1 ). Although incidents of human-crocodile conflict were reported in all age groups, the majority of victims $(77.16 \%)$ were $18-50$ years of age. Only 11.02 and $11.81 \%$ of victims were $>50$ and $<18$ years of age, respectively (Table 1 ). Only one fisher $<18$ years of age and two crab collectors $<18$ years of age were victims. The age and primary occupation of the victims were significantly associated $\left(\chi^{2}=17.075, \mathrm{df}=9, \mathrm{P}<0.1\right)$.

Considering all aquatic occupations together, $74.02 \%$ of incidents were fatal (Table 1). Fatalities were highest in nonvulnerable occupations ( $86.67 \%$; including those unrelated to the aquatic environment), and lowest among fishers (58.62\%). The death rate was lower (66.7\%) among Muslims than among Hindus (74.38\%; Table 1). Among castes, mortality was higher (91.67\%) among scheduled tribes than among scheduled castes $(73.85 \%)$ and the general population $(70.46 \%)$.
The peak month for attacks was December, during which $20.47 \%$ of attacks took place (Fig. 2). The lowest number of attacks occurred in September (4.72\%). Most incidences occurred during November and the winter months of December-February (41.73\%) followed by 3 months in the monsoon season (June-August; 20.47\%).

Crocodile attacks are more likely to occur during the day than at night: $37.01 \%$ of the recorded attacks took place during $08.00-11.00,23.62 \%$ during 11.00-14.00, and $27.56 \%$ during 14.00-17.0o. The majority of killings (88.19\%) occurred during $08.00-17.00$, when most human activity took place (Fig. 3). Of the $11.81 \%$ killed or injured at other times of the day, most were attacked in their boats while travelling to (05.00-08.00; 5.51\%) or returning from (17.00-19.00; $6.30 \%$ ) their occupations (Fig. 3).

The greatest number of crocodile attacks were recorded from Gosaba block (34.65\%), followed by Patharpratima (25.20\%), Namkhana (18.11\%) and Kultali (14.17\%; Table 2). Basanti (7.87\%) was the least affected block. The mortality rate from attacks was high $(62.20 \%)$, with a minimum of $50 \%$ in Patharpratima and maximum of $80 \%$ in Basanti. The mean annual number of deaths was 5.64 , with a minimum of 0.57 in Basanti and a maximum of 2.21 in Gosaba. Mean annual vulnerability and mortality rates per 10,000 people were 0.07 and 0.04 , respectively, with the greatest vulnerability (0.13) and mortality (o.09) in Gosaba.

The percentage distribution of conflicts (Table 3 ) across rivers indicates that the greatest number of attacks occur in the Thakuran (in Patharpratima) followed by Pirkhali 


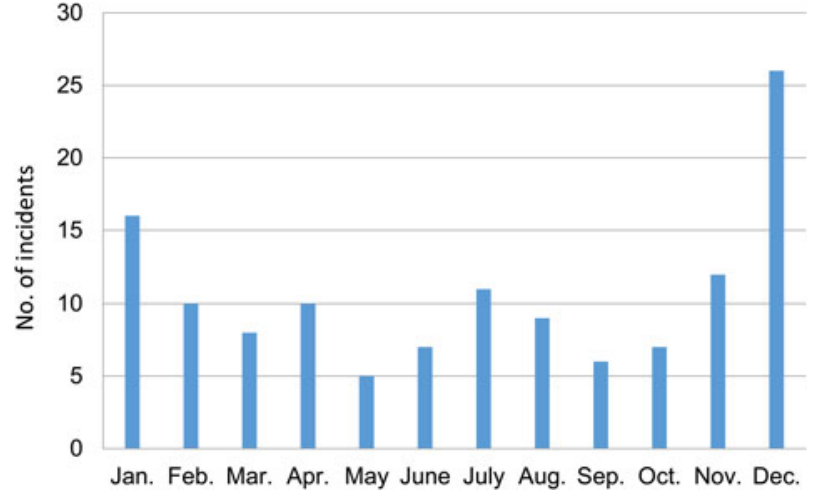

FIG. 2 Monthly distribution of crocodile Crocodylus porosus attacks in the Indian Sundarban (Fig. 1) during 2000-2013, as reported in surveys of 1,315 households in five study blocks.

(in Gosaba), Muriganga (in Namkhana), Nuchara (in Patharpratima) and Kaikalmari (in Kultali). These five rivers account for $55.2 \%$ of conflicts.

There were fewer male victims $(44.88 \%)$ than females (55.12\%; Fig. 4), probably because more women than men are involved in the collection of tiger prawns and crabs. Fishers are generally young males, 30-65 years of age. From 2000 to 2008 there was an increasing number of attacks on people $\left(R^{2}=0.80\right)$, with generally 11 incidents per year from 2008 onwards.

Circa $63 \%$ of the respondents expressed the idea that simply sharing the same habitat was the major reason for human-crocodile conflict; $18 \%$ said that the depleted prey base caused crocodiles to search for food; $10 \%$ said that crocodiles were man-eaters, and therefore attacks were inevitable; and $9 \%$ had no opinion about why conflicts occur.

\section{Discussion}

\section{Causes of conflict}

Conflict is likely to occur in any crocodile-occupied habitat where there is human activity. Crocodilians are among the few species that cause reflexive fear in humans, perhaps because the fear of being eaten is greater than the fear of being bitten (Graham, 1990). Many species will bite but only a few attack people as they would other prey items (Caldicott et al., 2005). Our questionnaire was designed to understand the causes of conflict, considering these factors.

Fishing activities are prevalent in the Sundarban, contributing to the livelihoods of $15 \%$ of the population (Sengupta \& Rao, 2003). Increasing human activity, such as large-scale collection of tiger prawn seeds, and a high frequency of crossing creeks for collection of forest products result in crocodile attacks. The mud flats on both sides of forest canals are potentially among the most likely areas of

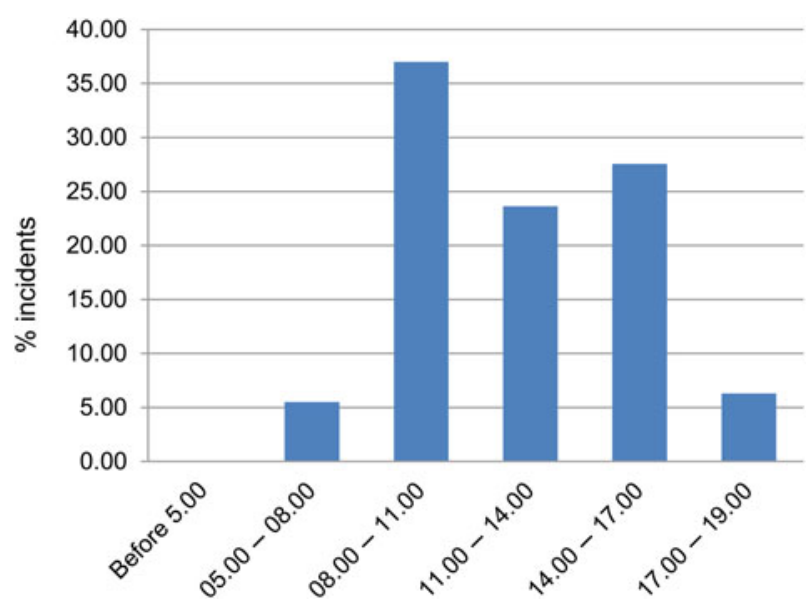

FIG. 3 Percentage cumulative frequency of crocodile attacks at various time periods study blocks (Fig. 1).

crocodile occurrence. As saltwater crocodiles consume fish (e.g. Oreochromis mossambicus, O. niloticus, Etroplus suratensis, Channa striata, Lates sp.) there is perceived competition for the same food source (Amarasinghe et al., 2015). Creeks or small rivers in the Sundarban are more perilous than large rivers, as crocodiles prefer muddy riverbanks during low tide for thermoregulation, and these habitats are not always available in large rivers.

As prawn seed collectors prefer to work in waist-deep water, crocodile attacks are common at low tide when mud flats on both sides of the creeks are exposed. In many cases collectors have suffered deformities from such attacks, and many have been killed (Chowdhury et al., 2008). Large-scale prawn seed collection and overfishing are responsible for the low availability of fish in the Sundarban. Human-crocodile conflict is sometimes attributed to overfishing of some of the crocodile's main food sources, leading crocodiles to hunt other prey, including people (Uragoda, 1994; Rao, 1996; Anderson \& Pariela, 2005).

The incidence of crocodile attacks in the Sundarban is difficult to quantify. Undoubtedly, more people have been attacked by crocodilians than have been reported, but the level of threat is thought to be comparatively low compared to that from snakes and tigers, which are responsible for as many as 40.54 and $31.3 \%$, respectively, of deaths caused by wildlife each year, on average (Das \& Bandyopadhyay, 2012).

\section{Pattern of conflict}

Several authors have reported that crocodile attacks increase in warm summer months (Fergusson, 2004; Caldicott et al., 2005), but in the Sundarban attacks are distributed throughout the year, with peaks occurring during the monsoon (June-August), in November and during the winter (December-February). Early monsoon is the main fishing season in the Sundarban, when thousands of prawn seed 
TABLE 2 Data on the characteristics of the five blocks in the Indian Sundarban where data were collected (Fig. 1) and on the number of incidents of attack by crocodiles during surveys of 1,315 households during 2000-2013.

\begin{tabular}{|c|c|c|c|c|c|c|}
\hline & \multicolumn{5}{|l|}{ Block } & \multirow[b]{2}{*}{ Total } \\
\hline & Gosaba & Namkhana & Patharpratima & Kultali & Basanti & \\
\hline Area $\left(\mathrm{km}^{2}\right)$ & 296.73 & 370.62 & 448.48 & 306.18 & 404.21 & $1,826.22$ \\
\hline Population (2011) & 246,598 & 182,830 & 331,823 & 229,053 & 336,713 & $1,327,017$ \\
\hline No. of households (2011) & 58,197 & 41,433 & 70,818 & 45,099 & 70,818 & 286,365 \\
\hline Number of incidents & 44 & 23 & 32 & 18 & 10 & 127 \\
\hline$\%$ of all incidents $(\mathrm{n}=127)$ & 34.65 & 18.11 & 25.20 & 14.17 & 7.87 & 100 \\
\hline No. of deaths & 31 & 13 & 16 & 11 & 8 & 79 \\
\hline$\%$ of deaths (of all incidents in the block) & 70.46 & 56.52 & 50.00 & 61.11 & 80.00 & 62.20 \\
\hline Mean no. of incidents annually & 3.14 & 1.64 & 2.29 & 1.29 & 0.71 & 9.07 \\
\hline Mean no. of deaths annually & 2.21 & 0.93 & 1.14 & 0.79 & 0.57 & 5.64 \\
\hline $\begin{array}{l}\text { Vulnerability per } 10,000 \text { people (no. of attacks } \times 10,000 / \text { total } \\
\text { population) }\end{array}$ & 0.13 & 0.11 & 0.07 & 0.06 & 0.02 & 0.07 \\
\hline $\begin{array}{l}\text { Mortality per } 10,000 \text { people (no. of fatal attacks } \times 10,000 / \text { total } \\
\text { population) }\end{array}$ & 0.09 & 0.05 & 0.04 & 0.03 & 0.02 & 0.04 \\
\hline
\end{tabular}

TABLE 3 Rivers in the five study blocks of the Indian Sundarban (Fig. 1) where frequent crocodile attacks occurred during 20002013.

\begin{tabular}{lll}
\hline $\begin{array}{l}\text { River/creek } \\
\text { (mean width) }\end{array}$ & Block & $\begin{array}{l}\text { \% of total } \\
\text { incidents }(\mathrm{n}=127)\end{array}$ \\
\hline Pirkhali $(150 \mathrm{~m})$ & Gosaba & 10.6 \\
Gomdi $(150 \mathrm{~m})$ & Gosaba & 3.8 \\
Korankhali $(100 \mathrm{~m})$ & Gosaba & 4.8 \\
Rangabeliya $(600 \mathrm{~m})$ & Gosaba & 2.9 \\
Bidya $(250 \mathrm{~m})$ & Gosaba & 8.7 \\
Saptamukhi $(800 \mathrm{~m})$ & Namkhana & 7.7 \\
Muriganga $(750 \mathrm{~m})$ & Namkhana & 9.7 \\
Nuchara $(200 \mathrm{~m})$ & Patharpratima & 9.7 \\
Thakuran $(550 \mathrm{~m})$ & Patharpratima & 15.5 \\
Matla $(400 \mathrm{~m})$ & Basanti & 5.8 \\
Bidya $(250 \mathrm{~m})$ & Basanti & 1.9 \\
Kaikalmari $(300 \mathrm{~m})$ & Kultali & 9.7 \\
Ajmalmari $(350 \mathrm{~m})$ & Kultali & 4.8 \\
Others & & 4.2 \\
\hline
\end{tabular}

collectors enter the creeks. In winter, the crocodile mating season starts and crocodiles become aggressive to other large crocodiles. Fewer encounters with crocodiles are reported in the post-monsoon season (August-October), when the water level in rivers is high, associated with higher frequencies of tropical cyclones, which discourages people from fishing and collecting prawn seed.

\section{Fatality rate}

The fatality rate associated with human-crocodile conflict in the Sundarban is high $(62.2 \%$ of attacks) compared to other parts of the world. In Australia $28.4 \%$ of attacks by saltwater crocodiles since 1971 have been fatal (Manolis \& Webb, 2013). The fatality rate in Sri Lanka (23.7\%, 19702008; de Silva, 2010) is similar to that in Australia. Fatality

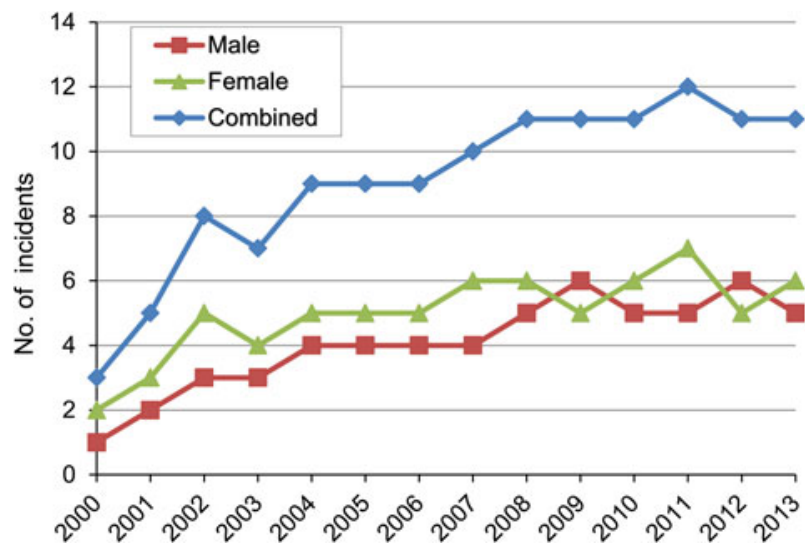

FIg. 4 Numbers of incidents of crocodile attacks on men and women, and combined, during 2000-2013, as reported in surveys of 1,315 households in the five study blocks (Fig. 1).

rates of $43.7-61 \%$ and $45.5 \%$ have been reported for Malaysian Borneo (Ambu, 2011; Tisen et al., 2011) and India's Bhitarkanika Wildlife Sanctuary, respectively (Gopi \& Pandav, 2009). A similar study was conducted in Mozambique during July 2006-September 2008, in which a $79 \%$ mortality rate was observed among people attacked by crocodiles (Dunham et al., 2010). Another similar study found a relatively high fatality rate $(63 \%)$ in mainland Africa (Fergusson, 2004). In comparison, only $7.6 \%$ of unprovoked attacks by American alligators in the USA have been fatal (Conover \& Dubow, 1997), which probably reflects the smaller size and less aggressive nature of this crocodilian species.

The higher rate of fatality in the Sundarban is attributable to sudden encounters with crocodiles in inaccessible places. Fishers and prawn seed collectors are most affected, as they venture illegally into deep jungle, far from villages or forest offices, where they do not have access to medical treatment if attacked. 


\section{Review of management issues}

Habitat loss and degradation are the key factors affecting the natural habitat of the saltwater crocodile (Amarasinghe et al., 2015) in the Sundarban. Habitat restoration, including the reintroduction of mangroves on government-owned lands, and restricting the issuing of new permits for forest users are part of a Forest Department strategy for shortand long-term projects. A crocodile sanctuary was set up in 1978 at Bhagabatpur in Patharpratima block, under the auspices of the Crocodile Project, which works to increase the number of saltwater crocodiles. This crocodile-breeding facility harbours the largest number of estuarine crocodiles in India, with an egg to hatching ratio of $>70$ (Singh, 2015).

A crocodile rearing centre was also established in the same locality in 1994 . By 2012, 312 crocodiles $(1-1.5 \mathrm{~m}$ in size) of various ages reared in Bhagabatpur Crocodile Project had been released in rivers of the Sundarban. Monitoring of crocodiles in the Sundarban is difficult because the mudflats where crocodiles bask are often inundated. Also, because of the high human population density and poverty, the socio-economic dependency of people on wetland habitats cannot be controlled.

A large number of crocodiles, both juveniles and adults, are poached from the Sundarban each year (Das \& Bandyopadhyay, 2012). Crocodile skins are valuable as they are used to make luxury items (Das \& Bandyopadhyay, 2012). The Forest Department endeavours to prevent poaching, but with limited success as its resources are limited. Occasionally, crocodiles stray to village ponds and are rescued. This is a frequent phenomenon in September and October in Patharpratima block. This is the time when crocodiles are reported to start nesting (Amarasinghe et al., 2015). The Forest Department has started to translocate crocodiles from areas of conflict, and 12 individuals were translocated during the study period (Vyas, 2012). However, saltwater crocodiles have a strong homing instinct and may return to the original capture site (Webb \& Manolis, 1989; Walsh \& Whitehead, 1993; Read et al., 2007).

Responses to human-wildlife conflict are varied and occur at various social-organizational scales involving actors with sometimes conflicting objectives (Mosimane et al., 2014). Thus, we must consider carefully how we use the term human-wildlife conflict, and distinguish clearly between human-wildlife interactions and the underlying conflicts between conservation and other human interests (Redpath et al., 2015).

\section{Conclusion}

In India there is little concerted effort to mitigate conflicts between people and crocodiles (Stevenson et al., 2014), and the Forestry Department is not actively involved in addressing the problem of crocodile attacks in the Sundarban because of the low intensity of the problem compared to human-tiger conflicts. Crocodiles are opportunistic predators that are most dangerous in water and at the water-land interface (Webb \& Manolis, 1998), and both primary (avoiding an attack altogether) and secondary preventive techniques (minimizing the harm after an attack has occurred) should be considered in addressing human-crocodile conflict (Caldicott et al., 2005). Primary prevention involves minimizing contact between people and crocodilians. Generating awareness about crocodile behaviour and the risk of prawn larvae collection by drag-netting may help people avoid attack. Banning or restricting tiger prawn and crab collection in areas of high crocodile density could also reduce the number of attacks. People whose primary occupation is non-vulnerable and who collect tiger prawns or crabs as a secondary occupation suffer a higher fatality rate and should be discouraged from collecting these resources from the creeks or rivers of the Sundarban. Existing management practices cannot eliminate the risk of crocodile attack while ensuring the conservation of the Sundarban ecosystem, and therefore a comprehensive management plan is urgently needed to reduce dependency on forest resources by introducing sustainable rural livelihood schemes (e.g. tourism, rainwater harvesting for multi cropping, poultry farming) while maintaining the ecosystem through enforcing restrictions on access to the forest. Providing training and education, microcredit and access to feasible markets is, however, a challenge for government bodies and local NGOs.

\section{Acknowledgements}

CSD is grateful to the University Grants Commission of the Government of India for providing financial support for field work in the Sundarban. We thank Professor Sunando Bandyopadhyay of the University of Calcutta and the retired wildlife biologist Carl D. Mitchell for their continuous inspiration and valuable suggestions for improving the article. We thank Dr Aznarul Islam of Aliah University, Suman Mondal, Saptarshi Sarkar, and Martin Fisher for assistance in producing the map figure.

\section{Author contributions}

This article is a joint effort by CSD and RJ.

\section{References}

Amarasinghe, A.A.T., Madawala, M.B., Karunarathna, D.M.S. S., Manolis, S.C., De Silva, A. \& Sommerlad, R. (2015) Humancrocodile conflict and conservation implications of saltwater crocodiles Crocodylus porosus (Reptilia: Crocodylia: Crocodylidae) in Sri Lanka. Journal of Threatened Taxa, 7, 7111-7130. 
Ambu, L. (2011) Current status of crocodiles in Sabah. In Proceedings of the International Crocodile Conference, Kuching, Sarawak, Malaysia, 19-21 October 2011.

Anderson, J. \& Pariela, F. (eds) (2005) Strategies to Mitigate Human-Wildife Conflicts: Mozambique. Report for the National Directorate of Forests and Wildlife, Mozambique. Food and Agriculture Organization of the United Nations, Rome, Italy.

Caldicott, D.G.E., Croser, D., Manolis, C., Webb, G. \& Britton, A. (2005) Crocodile attack in Australia: an analysis of its incidence and review of the pathology and management of crocodilian attacks in general. Wilderness \& Environmental Medicine, 16, 143-159.

Census of India (2011) Http://censusindia.gov.in/. Office of the Registrar General and Census Commissioner, New Delhi, India.

Chaudhuri, A.B. (2007) Biodiversity of Mangroves. Daya Publishing House, New Delhi, India.

Chaudhuri, A.B. \& Choudhury, A. (1994) Mangroves of the Sundarban. Volume 1: India. IUCN, Gland, Switzerland.

Chowdhury, A.N., Mondal, R., Brahma, A. \& Biswas, M.K. (2008) Eco-psychiatry and environmental conservation: study from Sundarban Delta, India. Environmental Health Insights, 2, 61-76.

Conover, M.R. \& Dubow, T.J. (1997) Alligator attacks on humans in the United States. Herpetological Review, 28, 120-124.

Curtis, S.J. (1933) Working Plan for the Forests of the Sundarban Division for the Period from 1st April 1931 to 31st March 1933. Bengal Government Press, Calcutta, India.

Dickman, A.J., Macdonald, E.A. \& Macdonald, D.W. (2011) A review of financial instruments to pay for predator conservation and encourage human-carnivore coexistence. Proceedings of the National Academy of Sciences of the United States of America, 108, 13937-13944.

Das, C.S. \& Bandyopadhyay, S. (2012) Sharing Space: HumanAnimal Conflicts in Indian Sundarban. Progressive Publishers, Kolkata, India.

DE Silva, A. (2010) Crocodiles of Sri Lanka: Preliminary Assessment of their Status and the Human-Crocodile Conflict Situation. Unpublished reported submitted to Mohamed bin Zayed Species Conservation Fund, Gampola, Sri Lanka.

Dunham, K.M., Ghiurghi, A., Cumbi, R. \& Urbano, F. (2010) Human-wildlife conflict in Mozambique: a national perspective, with emphasis on wildlife attacks on humans. Oryx, 44, 185-193.

FERGUSSON, R.A. (2002) Living with a wild predator: managing human-crocodile conflict in Africa. Crocodile Specialist Group Newsletter, 21, 16-20.

Fergusson, R.A. (2004) Preliminary analysis of data in the African human-crocodile conflict database. Crocodile Specialist Group Newsletter, 23, 21-22.

Glen, A.S., Dickman, C.R., Soulé, M.E. \& Mackey, B.G. (2007) Evaluating the role of the dingo as a trophic regulator in Australian ecosystems. Austral Ecology, 32, 492-501.

Gopi, G.V. \& PANDAV, B. (2009) Humans sharing space with Crocodylus porosus in Bhitarkanika Wildlife Sanctuary: conflicts and options. Current Science, 96, 459-460.

Graham, A. (1990) Eyelids of Morning: The Mingled Destinies of Crocodiles and Men. Chronicle Books, San Francisco, USA.

INSKip, C. \& ZimMERMANN, A. (2009) Human-felid conflict: a review of patterns and priorities worldwide. Oryx, 43, 18-34.

KHan, M.M.H. (2002) The Sundarban. In Wilderness: Earth's Last Wild Places (eds R.A. Mittermeier, C. Goettsch Mittermeier, P. Robles Gil \& J. Pilgrim), pp. 280-289. Conservation International, Arlington, USA.

Lamarque, F., Anderson, J., Fergusson, R., Lagrange, M., Osei-Owusu, Y. \& B A Kker, L. (2009) Human-Wildlife Conflict in Africa: Causes, Consequences and Management Strategies. Food and Agriculture Organization of the United Nations, Rome, Italy.
Leslie, A.J. \& Spotila, J.R. (2001) Alien plant threatens Nile crocodile (Crocodylus niloticus) breeding in Lake St. Lucia, South Africa.

Biological Conservation, 98, 347-355.

LANGLEY, R.L. (2005) Alligator attacks on humans in the United States. Wilderness \& Environmental Medicine, 16, 119-124.

MACGREGOR, J. (2002) International trade in crocodilian skins: review and analysis of the trade and industry dynamics for market-based conservation. In 16th Working Meeting of the IUCN SSC Crocodile Specialist Group, pp. 12-18. IUCN Crocodile Specialist Group, Gland, Switzerland.

Mandal, A.K. \& NANDi, N.C. (1989) Fauna of Sundarban Mangrove Ecosystem, West Bengal, India. Zoological Survey of India, Kolkata, India.

Manolis, S.C. \& Weвв, G.J.W. (2013) Production Implications of Trace Element Concentrations in Crocodile Eggs and Tissues. RIRDC Publication No. 12/140, Rural Industries Research and Development Corporation, Wagga Wagga, Australia.

McGregor, J. (2005) Crocodile crimes: people versus wildlife and the politics of postcolonial conservation on Lake Kariba, Zimbabwe. Geoforum, 36, 353-369.

McManus, J.S., Dickman, A.J., Gaynor, D., Smuts, B.H. \& Macdonald, D.W. (2015) Dead or alive? Comparing costs and benefits of lethal and non-lethal human-wildlife conflict mitigation on livestock farms. Oryx, 49, 687-695.

Milner-Gulland, E.J. \& Rowcliffe, M.J. (2007) Conservation and Sustainable Use. A Handbook of Techniques. Oxford University Press, New York, USA.

Mosimane, A.W., McCool, S., Brown, P. \& Ingrebretson, J. (2014) Using mental models in the analysis of human-wildlife conflict from the perspective of a social-ecological system in Namibia. Oryx, 48, 64-70.

Pargiter, F.E. (1934) A Revenue History of the Sundarban from 1765 to 1870. Bengal Government Press, Calcutta, India.

RAO, M.V.S. (1996) Nesting behaviour of the Indian crocodiles, Gavialis gangeticus, Crocodylus palustris and Crocodylus porosus. In Readings in Behaviour (eds R. Ramamurthi \& Geetabali), pp. 212-216. Newage International Ltd, New Delhi, India.

Read, M.A., Grigg, G.C., Irwin, S.R., Shanahan, D. \& Franklin, C.E. (2007) Satellite tracking reveals long distance coastal travel and homing by translocated estuarine crocodiles, Crocodylus porosus. PLos ONE, 2(9), e949.

Redpath, S.M., Bhatia, S. \& Young, J. (2015) Tilting at wildlife: reconsidering human-wildlife conflict. Oryx, 49, 222-225.

Ross, J.P. (1998) Crocodiles: Status Survey and Conservation Action Plan, 2nd edition. IUCN Species Survival Commission, Crocodile Specialist Group, Gland, Switzerland.

Sengupta, S. \& Rao, P. (2003) Adverse Impacts of Climate Change: Perception and Responses of Local Community. UNFCCC Expert Workshop on Local Coping Strategies for Adaptation, 12-13 November 2003, New Delhi, India.

SiNGH, S.S. (2015) Crocodile project at Sundarban gets a boost with expert assistance. The Hindu, 25 January 2015. Http://www. thehindu.com/todays-paper/tp-national/crocodile-project-atsunderbans-gets-a-boost-with-expert-assistance/article6819514.ece [accessed 9 February 2017].

Stevenson, C., de Silva, A., Vyas, R., Nair, T., Mobaraki, A. \& Chaudhry, A.A. (2014) Human-crocodile conflict in South Asia and Iran. Proceedings of the 23 rd Working Meeting of the IUCN-SSC Crocodile Specialist Group. IUCN, Gland, Switzerland.

Tisen, O.B., Ahmad, R., Kwan, S., Robi, N. \& Osaka, V. (2011) Promoting awareness on human-crocodile conflict in Sarawak. In Proceedings of the International Crocodile Conference, Kuching, Sarawak, Malaysia, 19-21 October 2011. 
Thorbjarnarson, J. B. (1992) Crocodiles: An Action Plan for Their Conservation. IUCN, Gland, Switzerland.

Uragoda, C.G. (1994) Wildlife Conservation in Sri Lanka: A History of Wildife and Nature Protection Society of Sri Lanka, 1894-1994. Wildlife and Nature Protection Society, Colombo, Sri Lanka.

Vyas, P. (2012) Biodiversity conservation in Indian Sundarban in the context of anthropogenic pressures and strategies for impact mitigation. PhD thesis. Saurashtra University, Rajkot, India.

Walsh, B. \& Whitehead, P.J. (1993) Problem crocodiles, Crocodylus porosus, at Nhulunbuy, Northern Territory: an assessment of relocation as a management strategy. Wildlife Research, 20, 127-135.

Webi, G. \& Manolis, C. (1989) Crocodiles of Australia. Reed Books, Frenchs Forest, Australia.

Webi, G. \& Manolis, C. (1998) Australian Crocodiles. Reed New Holland, Sydney, Australia.
Weladit, R.B. \& Tchamba, M.N. (2003) Conflict between people and protected areas within the Bénoué Wildlife Conservation Area, North Cameroon. Oryx, 37, 72-79.

Woodroffe, R., Lindsey, P., Romañach, S., Stein, A. \& ole RANAH, S.M.K. (2005) Livestock predation by endangered African wild dogs (Lycaon pictus) in northern Kenya. Biological

Conservation, 124, 225-234.

\section{Biographical sketches}

Chandan Surabhi Das's research focuses on socio-economic aspects of human-wildlife conflict in the protected areas of developing countries. He is also conducting extensive research on the conservation of the Sundarban mangrove forests in the context of the livelihood of forest users. RABINDRANATH JANA has experience in conducting statistical analysis of socio-eco-demographic data. His research interest is in social network analysis. 